The University of Maine

DigitalCommons@UMaine

Marine Sciences Faculty Scholarship

School of Marine Sciences

$1-1-2006$

\title{
Potential of Argo drifters for estimating biological production within the water column
}

\author{
Seung Hyun Son \\ University of Maine \\ Emmanuel Boss \\ University of Maine, emmanuel.boss@maine.edu \\ Jae Hoon Noh \\ Korea Institute Of Ocean Science \& Technology
}

Follow this and additional works at: https://digitalcommons.library.umaine.edu/sms_facpub

Part of the Oceanography and Atmospheric Sciences and Meteorology Commons

\section{Repository Citation}

Son, Seung Hyun; Boss, Emmanuel; and Noh, Jae Hoon, "Potential of Argo drifters for estimating biological production within the water column" (2006). Marine Sciences Faculty Scholarship. 192. https://digitalcommons.library.umaine.edu/sms_facpub/192

This Article is brought to you for free and open access by DigitalCommons@UMaine. It has been accepted for inclusion in Marine Sciences Faculty Scholarship by an authorized administrator of DigitalCommons@UMaine. For more information, please contact um.library.technical.services@maine.edu. 


\title{
Potential of Argo Drifters for Estimating Biological Production within the Water Column
}

\author{
SeungHyun Son ${ }^{1 *}$, Emmanuel Boss ${ }^{1}$, and Jae Hoon Noh ${ }^{2}$ \\ ${ }^{\prime}$ School of Marine Sciences, University of Maine, Orono, ME 04469, USA \\ ${ }^{2}$ Marine Ecosystem \& Conservation Research Division, KORDI, Ansan P.O. Box 29, Seoul 425-600, Korea
}

Received 15 June 2006; Revised 20 June 2006; Accepted 23 June 2006

\begin{abstract}
Argo drifters provide information of the vertical structure in the water column and have a potential for the improvement of understanding phytoplankton primary production and biogeochemical cycles in combination with ocean color satellite data, which can obtain the horizontal distribution of phytoplankton biomass in the surface layer. Our examples show that using Argo drifters with satellite-measured horizontal distribution of phytoplankton biomass at the sea surface allow an improved understanding of the development of the spring bloom. The other possible uses of Argo drifter are discussed.
\end{abstract}

Key words - Argo drifter, Ocean Color, Phytoplankton bloom, SeaWiFS, MODIS

Ocean color remote sensing instruments such as the Coastal Zone Color Scanner (CZCS), the Sea-viewing Wide Field-of-view Sensor (SeaWiFS), and Moderate Resolution Imaging Spectroradiometer (MODIS) have a major advantage in overcoming the temporal and spatial limitation of ship measurements. For about the last three decades, ocean color remote sensing has contributed to understanding primary productivity in the ocean as well as distribution of carbon sources and sinks on the basin to global scale (Platt et al. 1991; Sathyendranath et al. 1991; Longhurst et al. 1995; Behrenfeld and Falkowski 1997). However, a significant limitation of satellite-based data is that only information on the surface layer can be determined. For estimating more accurate biological production and carbon distribution within the water column, information on the vertical structure of parameters such as the chlorophyll concentration and mixed-layer depth is required.

\footnotetext{
*Corresponding author. E-mail: oceancolor.son@gmail.com
}

Model studies have attempted to derive the profiles of phytoplankton biomass from the remotely-sensed chlorophyll concentration for thermally stratified waters (Platt et al. 1988; Morel and Berthon 1989; Mueller and Lange 1989). Mixed-layer depth has also been derived from satellite data such as AVHRR sea surface temperature (Yan et al. 1990) and GEOSAT satellite altimeter (Ali and Sharma 1994). However, the parameters are still poorly constrained by satellite observations.

Argo drifters provide information on the vertical structure of temperature and salinity. The Argo program has a broad-scale global array of profiling floats for continuous monitoring of the temperature and salinity of the upper $2000 \mathrm{~m}$ of the ocean. At present, about 2500 Argo drifters are deployed over the global ocean (for more details, see http://www.argo.ucsd.edu). A main purpose of the Argo project is to monitor physical oceanographic features such as the global heat balance and intermediate level circulation. However, Argo drifters have a potential for the improvement of understanding phytoplankton primary production and biogeochemical cycles in combination with ocean color satellite data, which can obtain the horizontal distribution of phytoplankton biomass in the surface layer.

Profiles of an individual Argo drifter are used to supplement ocean color images of chlorophyll-a concentration in the southwestern region of the East Sea in Figure 1. In early March (March $5^{\text {th }}-12^{\text {th }}$ ) of 2004, the spring bloom had not started yet although there were several patches of high chlorophyll-a concentration. The surface chlorophyll-a concentration from MODIS is about $1.0 \mathrm{mg} \cdot \mathrm{m}^{-3}$ at the position of the Argo drifter. Temperature and salinity profiles 

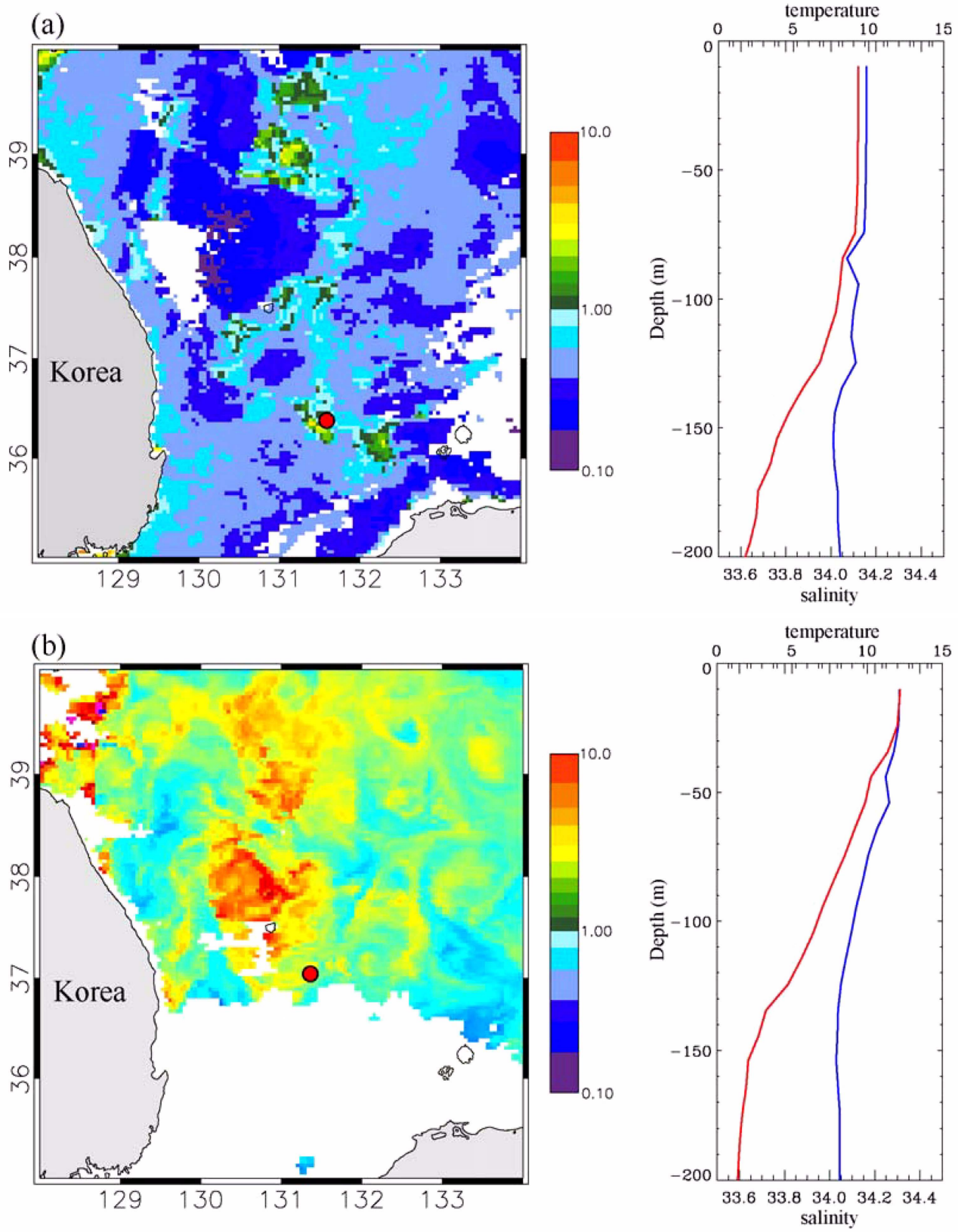

Fig. 1. 8-day composites of MODIS chlorophyll-a provided by NASA GSFC Distributed Active Archive Center are used at $4 \times 4 \mathrm{~km}$ spatial resolution over the eastern sea of Korea for periods of (a) March $5^{\text {th }}$ to $12^{\text {th }}$ (day of year 65 to 72 ) and (b) April $14^{\text {th }}$ to $21^{\text {st }}$ (day of year 105 to 112) in 2004. Profiles of temperature (red) and salinity (blue) observed by ARGO drifter in (a) March $2^{\text {nd }}$ (day of year 62) and (b) April $21^{\text {st }}$ (day of year 112), 2004 are also shown. Red circle with black border on the MODIS chlorophyll-a images indicate the position of the ARGO drifter.

of the Argo drifter show that the upper water column is well mixed down to about $75 \mathrm{~m}$. In mid-April (April $14^{\text {th }}-$ $21^{\text {st) }}$ ) of 2004, the spring bloom was well developed in the East Sea. The MODIS chlorophyll-a concentration is $2.19 \mathrm{mg} \cdot \mathrm{m}^{-3}$ at the position of the Argo profile. The water column is stratified with a mixed layer depth of about $25 \mathrm{~m}$. These results are consistent with Sverdrup's hypothesis
(Sverdrup 1953), which is that the spring bloom in midlatitude oceans occurs as the critical depth deepens with increasing incident light while the mixed layer depth shallows due to the strong stratification of the water column. In addition to the temperature and salinity sensors, active optical sensors have been installed on some Argo drifters. Chlorophyll-a fluorescence and scattering of particles 
(a)

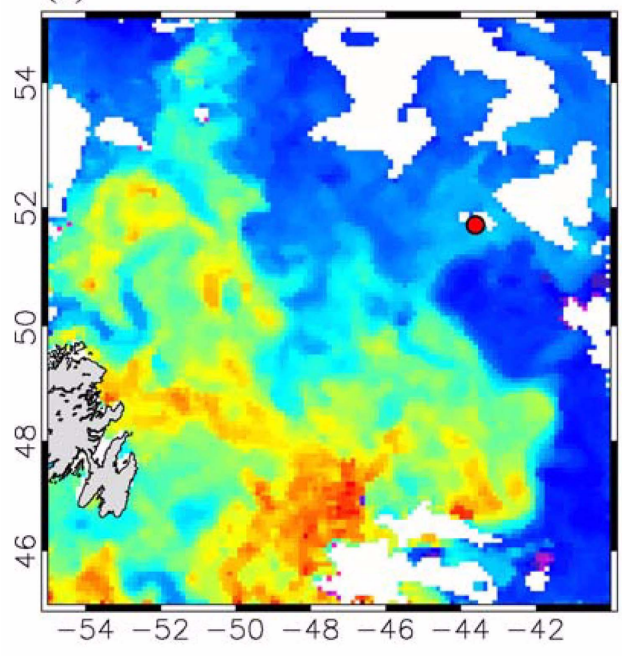

(b)

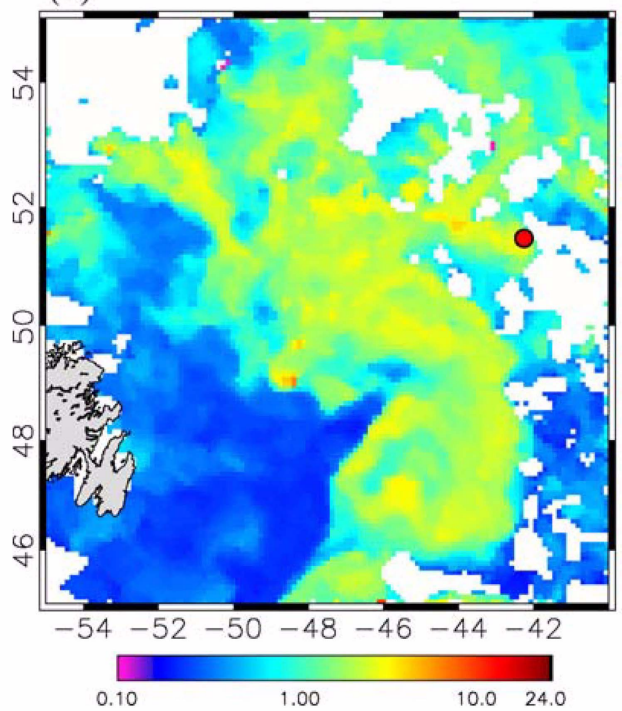

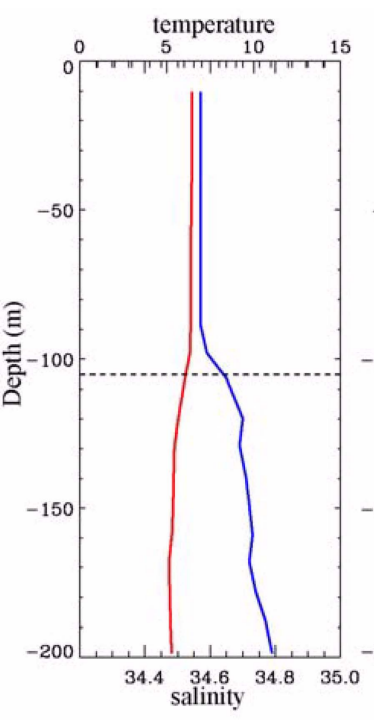
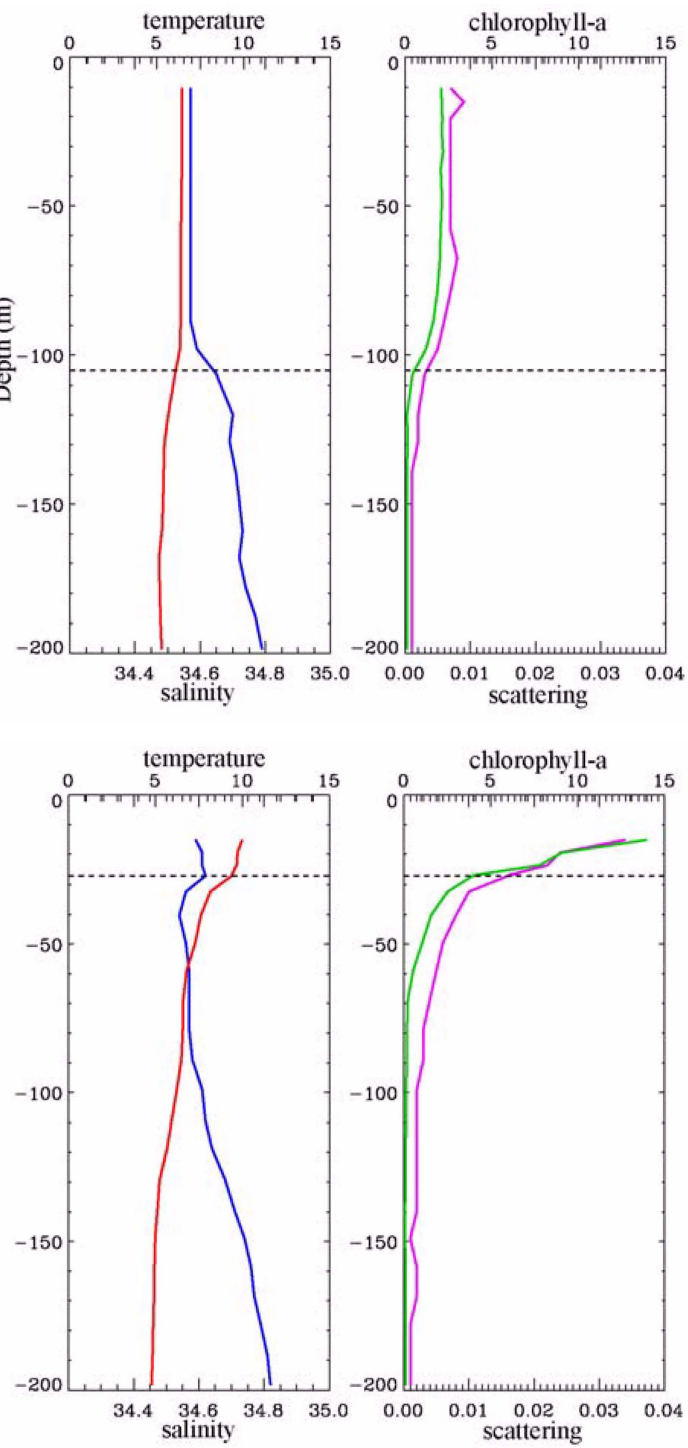

Fig. 2. 8-day composites of SeaWiFS chlorophyll-a provided by NASA GSFC Distributed Active Archieve Center are used at $9 \times 9 \mathrm{~km}$ spatial resolution over the Labrador Sea for periods of (a) April $15^{\text {th }}$ to $22^{\text {nd }}$ (day of year 105 to 112 ) and (b) May $17^{\text {th }}$ to $24^{\text {th }}$ (day of year 137 to 143) in 2005. Profiles of temperature (red), salinity (blue), chlorophyll-a fluorescence (green), and scattering coefficients (purple) observed by ARGO drifter in (a) April 13 ${ }^{\text {th }}$ (day of year 103) and (b) May 23 $3^{\text {rd }}$ (day of year 143), 2005 are also shown. Red circle with black border on the SeaWiFS chlorophyll-a images indicate the position of the ARGO drifter. Mixed-layer depth was calculated as the depth at which sigma-t changes by less than $0.125 \mathrm{~kg} \cdot \mathrm{m}^{-3}$ from the surface value (dotted lines).

measured by the sensors provide vertical estimates of phytoplankton biomass and particulate concentration in the water column. Profiles taken in spring 2005 in the Labrador Sea from an Argo drifter which carries biogeochemical sensors, as well as temperature and salinity sensors, are shown along with 8-day composite images of the SeaWiFS chlorophyll-a concentration (Fig. 2). On the SeaWiFS image in mid-April (April $15^{\text {th }}-22^{\text {nd }}$ ), no spring bloom has appeared over the northeastern area of the Labrador Sea while it has already started in the southwestern area. Mixed layer depth at the position of the Argo drifter is to about $106 \mathrm{~m}$ showing that the water column is vertically well mixed. Chlorophyll-a fluorescence is relatively low and uniform within the mixed layer. Although there are two small peaks, the vertical distribution of scattering coefficient is similar to that of the chlorophyll-a fluorescence since particulate concentration is mostly from biogenic sources in the open ocean. One month later 
(May $17^{\text {th }}-24^{\text {th }}$ ), the spring bloom has shifted to the northeastern area of the Labrador Sea. Similar to the result in the East Sea, strong stratification is shown in the upper layer with mixed layer depth of about $27 \mathrm{~m}$. Pronounced high chlorophyll concentration and scattering coefficient are shown in the surface layer. These results also show that the spring bloom is associated with watercolumn stratification (Sverdrup 1953).

Using Argo drifters with satellite-measured horizontal distribution of phytoplankton biomass at the sea surface allows an improved understanding of the development of the spring bloom. Further, the vertical information from the Argo drifter has a potential for more accurate estimates in vertically-resolved primary production using satellite-based primary production algorithm. Studies have shown that a uniform biomass profile underestimates integral primary production by $20-35 \%$ in the Kuroshio Current and frontal regions of the East China Sea (Siswanto et al. 2004 ) and by up to $39 \%$ in the central Yellow Sea (Son et al. 2005). Thus, the biomass profile from the Argo drifter would reduce the errors in estimating integrated primary production in the water column. In addition, sampling from the Argo drifter is currently taken every 5 to 10 days with about $10 \mathrm{~m}$ of depth interval. A future Argo drifter is planned which is able to measure vertical profiles with less than $1 \mathrm{~m}$ interval and whose floating cycle can also be controlled remotely. So better understanding of small scale variability in biological production would be expected.

Optical scattering coefficients have been shown to covary with the particulate organic carbon concentration and phytoplankton carbon biomass (Loisel and Morel 1998; Claustre et al. 1999; Behrenfeld and Boss 2003). Therefore, vertical profiles from the scattering sensor carried on the Argo drifter could also provide more information on the global carbon sources and sinks and how these are changing.

\section{Acknowledgments}

We thank NASA SeaWiFS and MODIS Projects, NASA Goddard Earth Science Data and Information Services Center/Distributed Active Archieve Center for production and distribution of the satellite chlorophyll-a data, and the Korean Argo Project of the Korea Ocean Research Development Institute (KORDI) for distribution of Argo drifter data. We appreciate Drs. Stephanie Henson, SangHeon Lee, and anonymous reviewers for valuable comments.

\section{References}

Ali, M.M. and R. Sharma. 1994. Estimation of mixed layer depth in the equatorial Indian Ocean using GEOSAT altimeter data. Mar. Geod., 17(1), 63-72.

Behrenfeld, M. and P. Falkowski. 1997. Photosynthetic rates derived from satellite-based chlorophyll concentration. Limnol. Oceanogr., 42(1), 1-20.

Behrenfeld, M. and E. Boss. 2003. The beam attenuation to chlorophyll ratio: An optical index of phytoplankton physiology in the surface ocean? Deep-Sea Res. I, 50, 1537-1549.

Claustre, H., A. Morel, M. Babin, C. Cailliau, D. Marie, J.-C. Marty, D. Tailliez, and D. Vaulot. 1999. Variability in particle attenuation and chlorophyll fluorescence in the tropical Pacific: Scales, patterns, and biogeochemical implications. $J$. Geophys. Res., 104, 3401-3422.

Loisel, H. and A. Morel. 1998. Light scattering and chlorophyll concentration in case 1 waters: A reexamination. Limnol. Oceanogr., 43, 847-858.

Longhurst, A., S. Sathyendranath, T. Platt, and C. Caverhill. 1995. An estimate of global primary production in the ocean from satellite radiometer data. J. Plank. Res., 17(6), 1245-1271.

Morel, A. and J.-F. Berthon. 1989. Surface pigments, algal biomass profiles, and potential production of the euphotic layer: Relationships reinvestigated in view of remote-sensing applications. Limnol. Oceanogr., 34(8), 1545-1562.

Muller, J.L. and R.E. Lange. 1989. Bio-optical provinces of the Northeast Pacific Ocean: A provisional analysis. Limnol. Oceanogr, 34(8), 1572-1586.

Platt, T., S. Sathyendranath, C. Caverhill, and M. Lewis. 1988. Ocean primary production and available light: Further algorithms for remote sensing. Deep-Sea Res., 35(6), 855-879.

Platt, T., C. Caverhill, and S. Sathyendranath. 1991. Basin-scale estimates of oceanic primary production by remote sensing: The North Atlantic. J. Geophys. Res., 96(8), 15147-15159.

Sathyendranath, S., T. Platt, E.P.W. Horne, W.G. Harrison, O. Ulloa, R. Outerbridge, and N. Hoepffner. 1991. Estimation of new production in the ocean by compound remote sensing. Nature, 353, 129-133.

Siswanto, E., J. Ishizaka, and K. Yokouchi. 2004. Estimating chlorophyll vertical profiles from satellite data and the implication to primary production in Kuroshio front of the East China Sea. J. Oceanogr., 61, 575-589.

Son, S., J. Campbell, M. Dowell, S. Yoo, and J. Noh. 2005. Primary production determined by ocean color remote sensing in the Yellow Sea. Mar. Ecology Prog. Ser., 303, 91-103.

Sverdrup, H.U. 1953. On conditions for the vernal blooming of phytoplankton. J. Cons. Int. Explor. Mer., 18, 287-295.

Yan, X.-H., J.R. Schubel, and D.W. Pritchard. 1990. Oceanic upper mixed layer depth determination by the use of satellite data. Remote Sens. Environ., 32(1), 55-74. 